\title{
The Impact of Inflation on Pakistan Stock Exchange
}

\author{
Mohammad Muzammil* Dr. Sohaib Uz Zaman Amna Asim Salwa Haider \\ Karachi University Business School, University of Karachi. Main University Road Karachi - 75270. Sindh, \\ Pakistan.
}

\begin{abstract}
The aim of the study is to determine the impact of inflation on equity prices in Pakistan's economy. The examination time frame is 2012-2018; monthly information was gathered from the State Bank of Pakistan and the Pakistan Stock Exchange. The information was dissected utilizing the relapse model and factual consequences of these investigations to demonstrate a negative connection among expansion and stock costs. All exploration as of late has demonstrated that inflation and stock costs have a positive relationship universally. Some studies, however, indicated that inflation and equity prices were negative. In general, the stock market provides an overview of investors whether they want to invest in the financial market. Equity prices also affect inflation.
\end{abstract}

Keywords Stock price, Inflation, Karachi Stock Exchange, KSE 100 index, CPI

DOI: $10.7176 / \mathrm{EJBM} / 11-16-11$

Publication date:June $30^{\text {th }} 2019$

\section{Introduction}

The equity markets are a trading venue where public companies' shares are sold and sold. In addition to the bond market that the lender's trade, stock exchanges are invaluable financial companies for companies. The behavior of the securities markets of the country can serve as a reliable indicator of the economy. The Karachi 100 FX index is an important stock market index that monitors the performance of the largest market share companies from each sector of Pakistan ehf. Registered on the Karachi Exchange, as of October 15, 2012, is a free float index. KSE 100 has an initial value of 1,000 from November 1991.

There are three noteworthy stock trades in Pakistan, the Karachi Stock Exchange (KSE), the Lahore Stock Exchange (LSE) and the Islamabad Stock Exchange (ISE). Be that as it may, on August 27, 2015, an understanding was marked in Islamabad to build up Pakistan's stock trade, which joins vendors of Karachi, Lahore, and Islamabad. Also, the securities exchange is estimated in files and the file is a technique for computing the exhibition of every single financial exchange. In this manner, there are various pointers in Pakistan that measure the financial exchange. Three of these lists are the most famous among the KSE, the KSE 30 list, the KSE 100 record, and the KSE All Stock Index (Ghulam et al., 2015).

Inflation is characterized as the expansion in normal costs for all merchandise and ventures over a given period and can likewise be characterized as a lasting increment in all-out costs, which means a reduction in buying power and an expansion in average cost for basic items (Mousa et al., 2012). In this way, expansion is kept up in a steady circumstance; the essential worry of money related arrangement creators is as expressed in financial approach goals national bank (Mishkin, 2004). This is on the grounds that swelling in a specific nation reflects monetary advancements and value solidness in that nation likewise influences a nation's exhibition on the universal market (Daniel Chidothi et al, 2013).

Different investigations break down the connection among profits and swelling over an any longer period. For instance, Jaffe and Mandelker (1976) found a negative connection between joint profit and swelling in short times for testing, yet this proportion ends up positive when the creators accept that the long haul is 1875-1970. This positive long haul inflationary impact is affirmed by Boudoukh and Richardson (1993) which manages the connection among gainfulness and swelling on US and British stock trades somewhere in the range of 1802 and 1990 (del Camino Torrecillas et al., 2013).

Because of scarce evidence, there has been a need to get a clear picture of Pakistan Stock Exchange in order to devise the strategies to control the inflation. The current study was planned to find the association between Inflation and Stock Prices, which would be helpful in paving way for future studies, researcher and policymakers.

\section{Literature Review}

Omran et al. (2001)examined the effect of inflation on the o Egyptian securities exchange performance is talked about with a parallel reconciliation investigation through the ECM. Accordingly, there was an extensive long haul and momentary connection between changes that affected swelling in the Egyptian financial exchange as a rule. 
Sohail et al. (2010) examined the effect of five macroeconomic changes on long haul and momentary lists to test the connection between the present moment and long haul Johannin coordination advancements and VECM. Furthermore, month to month information was utilized from November 1991 to June 2008. The record and the genuine swapping scale and the mechanical yield list relentlessly expanded in Pakistan, while cash and government securities were multiple times higher. Months had a negative long haul impact on stock costs.

LifangLi et al. (2010) examined the connection among expansion and protections sooner rather than later and present moment decides distinctive inflationary governments. UK information was utilized for this examination. It was discovered that the British securities exchange neglected to dispose of money related hazard for swelling in a brief span however to some degree blended. The outcome was that the connection between swelling and execution vacillates in various government inflation.

Qayyum, et al. (2011) utilized the Engel-Granger technique and bivariate EGARCH strategy. As per this technique, the aftereffects of the examination have demonstrated that an adjustment in the money related approach position significantly affects financial exchange variances.

Geetha et al. (2011) directed an investigation to decide the connection between swelling and protections exchanging. The examination uncovered that long haul connections are among desires and sudden swelling and yield. Nonetheless, there is no transient connection between these progressions for Malaysia and the United States however for China.

Yahyazadehfar et al. (2012) led an examination to research the effect of macroeconomic changes, for example, loan costs, lodging costs and gold costs on value costs in the capital region in Iran. The VAR model and the Johansen-Juselius merger technique were utilized so that a positive relationship between's the price tag and lodging costs, while the connection between's ostensible rates and gold costs with offer costs is negative. The consequences of medical aid precedents additionally demonstrate that stock costs respond in all respects rapidly. Moreover, explore results demonstrated that most vacillations in swelling can be credited to their own. Among the adjustments in lodging costs assume a key job in valuing.

Taofik et al. (2013) tried the long haul connection among productivity and swelling in Nigeria. Month to month information on the absolute stock value list from the Nigerian Stock Exchange and the Nigerian Consumer Price Index from January 1997 to 2010 were utilized and the Analytical Distribution Method (ARDL) was utilized. In this manner, the end is that there is an unmistakable long haul connection among expansion and stock productivity, however, for the time being, a moderate association with extra time results.

Salman Ali (2014) examined the KSE 100 stock index with a progression of macroeconomic changes in 2014. Various transformation and Pearson coefficients were utilized to discover the connection between the factors. The outcomes likewise show that the swapping scale, swelling and development rate are decidedly connected to the price tag (KSE-100 list). While adversely influencing the stock cost of the KSE-100 loan cost file.

Glulam et al. (2015) led an examination concentrate to clarify the connection between values and expansion in Pakistan. The consequences of the investigation uncovered a negative relationship between's stock and swelling.

Irum et al. (2015) made instances of expansion and stock costs. The VAR strategy is utilized. The judgment demonstrates that swelling negatively affects stock costs.

Rabia et al. (2015), this examination was led to explore the effect of macroeconomic changes on the Karachi stock trade. The consequences of the examination demonstrated that GDP, financing costs and swelling are exceptionally identified with the KSE list, however, loan costs have a negative relationship with the KSE trade.

Mula Nazar et al. (2016), the reason for this examination is to decide the effect of expansion on Pakistani financial exchange costs. The aftereffects of the investigation demonstrate a slight positive relationship between's expansion and stock costs.

Hanan AD et al. (2017), this study investigates the relationship between inflation and Jordanian stock market production. The method used was a single-pass, concatenation, and finally correction guide between 1978 and 2015. It turned out to be a short and long-lived relationship, as demonstrated by a statistically significant factor in the error correction model, and based on a catalytic response, we found some positive shock to commercial 
inflation causes an increase in deflator GDP and a positive shock (GDP deflator) does not create any significant impact on trading value.

Farooq et al. (2018), this examination talks about the connection between swelling and affectability of stock costs. Information on this examination was gathered from the 37 advertise and inferred that the organizations with high expansion rates are less powerless against stock costs than the organizations with low swelling as a result of the price tag. less enlightening in nations with high expansion.

Jawad et al. (2018), this investigation decides the effect of different macroeconomic changes in Pakistan stocks. Since all factors are at first look, the perfect ARDL way to deal with restricting testing is utilized to affirm present moment and long haul joining of macroeconomic stock changes. The outcomes recommend that costs in the Karachi securities exchange will significantly affect the long haul cash supply, conversion scale, and loan cost markets. For the time being, all factors are unessential, with the exception of the swapping scale of the króna, which negatively affects stock costs.

Donald et al. (2018), the purpose of this study was to examine the stochastic properties of the stock market, the yield on the stock market and the adjustment of their adjustment based on monthly data for the period 1993 to 2015 in Kenya. The method used to derive the result was an integrated moving average (ARFIMA) and partly an integrated correction system (FIECM). The results of the Arfima model show that monthly inflation, annual inflation, and stock market prices are unhealthy integration orders and that recessions include unhealthy integration orders, suggesting that the long-term, balance equilibrium and partially integrated correction mechanisms (FIECM) are emerging. Inflation between years has a positive effect on securities trading.

Sobia et al. (2019), the study was conducted to identify the relationship between the Pakistani stock market and inflation. Depending on the usual smallest square method, it does not relate to stock and inflation. This means that inflation does not affect the stock exchange in Pakistan.

Gulzar Ali et al. (2019), this study tries to assess Fisher's hypothesis that Pakistan's inventory surplus is a defense against inflation using monthly chronological data for 2000-2016. The study's findings support Fisher's hypothesis, both short-term and long-term bonds are for inflation protection in Pakistan. In addition, the study found a twoway link between return on equity and inflation. ARDL regression analysis, the Granger cause division of the ARDL-bound assay, ARDL integration, and long-term testing, analysis and stability were used as diagnostic techniques.

Jareno et al. (2019), talks about the conceivable financial exchange setting in six nations (Germany, Italy, Spain, France, UK, and the United States) and some significant macroeconomic factors, for example, GDP, the CPI and modern generation and joblessness (UNEMP). Gross domestic product and UNEMP have a positive connection with these worldwide securities exchanges.

\section{Hypothesis Testing}

H0: There is no relationship between inflation and stock prices in the economic growth of Pakistan.

H1: There is a relationship between inflation and stock prices in the economic growth of Pakistan.

\section{Research Question}

1. What is the relationship between the purchase price and inflation?

2. How does inflation affect stock prices?

3. What are the results of the purchase price and inflation?

\section{Problem Statement}

The stock exchange rate reflects the country economic growth and prosperity. Recently studies have shown that the recent trend of KSE-100 index negatively influences the stock prices. Inflation considered to be the main culprit for stock market volatility and risk. If inflation is expected, firms are less likely to hold shares, over time money loses its value.

\section{Scope of the Study}

The study has explored the effects of inflation on stock prices in Pakistan 
The objective of the Study

1. The aim of this study is to assess thecurrent trend in the KSE 100 index in Pakistan's economy.

2. Reestablished the effects of inflation on stock prices in Pakistan by evaluating its impact.

\section{Methodology and Results}

\section{Methodology}

a) Data Collection Technique

In this research,monthly time series data (secondary data) was used. The data was analyzed by using the Regression model to determine the impact of Inflation (CPI) on stock prices (KSE 100 index) in the last seven years (2012-2018).

b) Data Description

Inflation was targeted in this study, the consumer price index used as a proxy variable. The stock price data refers to the KSE 100 index. Both variable data were available monthly and collected in the State Bank of Pakistan's Statistical Bulletin.

c) Sources

Statistical Bulletin (State Bank of Pakistan).

Pakistan Stock Exchange (PSX).

d) Sample Size

The sample size consisted of 84 observations.

e) Statistical Test

SPSS software was used to analyze the data using the regression model. Inflation (CPI) taken as independent variable and Stock prices (KSE 100 index) as the dependent variable.

$$
\begin{aligned}
& \mathrm{Y}=\beta_{0}+\beta_{1} X_{1}+u_{i} \\
& \mathrm{SP}=\beta_{0}+\beta_{1}(C P I)+u_{i}
\end{aligned}
$$

$\mathrm{SP}=$ Stock Prices $($ KSE 100 Index $)$

$\mathrm{CPI}=$ Consumer Price Index (Inflation) 


\section{Results}

Table No. 1

Correlations

\begin{tabular}{|c|c|c|c|}
\hline & & $\begin{array}{c}\text { KSE } 100 \\
\text { NDTXX }\end{array}$ & CPI \\
\hline $\begin{array}{l}\text { KSE } 100 \text { INDEXX } \\
\text { PIUCES }\end{array}$ & $\begin{array}{l}\text { L'earson } \\
\text { Correlation } \\
\text { Sig. (2-tailed) } \\
\mathrm{N}\end{array}$ & $\begin{array}{l}1 \\
84\end{array}$ & $\begin{array}{l}.927^{\circ} \\
.000 \\
81\end{array}$ \\
\hline CPI & $\begin{array}{l}\text { Pearson } \\
\text { Correlation } \\
\text { Sig. (2-tailed) } \\
\mathrm{N}\end{array}$ & $\begin{array}{l}.927^{\circ} \\
.000 \\
81\end{array}$ & 84 \\
\hline
\end{tabular}

**. Correlation is significant at the 0.01 level (2-tailed).

This means that changes to one variable are very much associated with changes to another variable. The Pearson $\mathrm{r}$ is 0.927 , this number is close to 1 . Therefore, we can conclude that a strong relationship between variables exists. The sig. value ( 2 tails) is 0.000 this value is less than 0.05 . Therefore, there is a statistically significant relationship between changes between variables.

\section{Table No. 2}

\section{Model Summary}

\begin{tabular}{|r|r|r|r|l|l|}
\hline & & & & & \\
Model & $\mathrm{R}$ & R Square & \multicolumn{1}{l|}{$\begin{array}{l}\text { Adjusted R } \\
\text { Square }\end{array}$} & $\begin{array}{l}\text { Std. Error of } \\
\text { the Estimate }\end{array}$ & $\begin{array}{l}\text { Durbin- } \\
\text { Watson }\end{array}$ \\
\hline 1 & $.927^{\mathrm{a}}$ & .858 & .857 & 4065.70983 & .184 \\
\hline
\end{tabular}

a. Predictors: (Constant), CPI

\section{b. Dependent Variable: KSE 100 INDEX PRICES}

$\mathrm{R}$ is the association and measures how two variables interact with each other. R-squared is the degree of variability in the dependent variable represented by the free variable, where the square $r$ is balanced in additional reliable details because it takes into account the size of our sample, the variability of the default run value. In the model, the estimate of $\mathrm{R}$ indicates that there is a match between the observed and expected values of the subordinate variables. Here, the value of R-squared is 0.858 which means that there is $85.8 \%$ of the variation is explained by the model.

The Durbin-Watson statistic is 0.184 which varies from 1.624 to 1.671 and therefore the data is autocorrelated. 
Table No. 3

ANOVA

\begin{tabular}{|c|c|c|c|c|c|c|}
\hline \multicolumn{2}{|c|}{ Model } & $\begin{array}{l}\text { Sum of } \\
\text { Squares }\end{array}$ & df & Mean Square & F & Sig. \\
\hline \multirow[t]{3}{*}{1} & Regression & $8.223 \mathrm{E} 9$ & 1 & $8.223 \mathrm{E} 9$ & 497.465 & $.000^{\circ}$ \\
\hline & Residual & $1.355 \mathrm{E} 9$ & 82 & $1.653 \mathrm{E} 7$ & & \\
\hline & Total & $9.579 \mathrm{E} 9$ & 83 & & & \\
\hline
\end{tabular}

a. Predictors: (Constant), CPI

b. Dependent Variable: KSE 100 INDEX PRICES

Here sig. value (p-value) is 0.000 , which is less than 0.05 so we are rejecting the null hypothesis and accepting the alternative hypothesis

Table No. 4

\section{Coefficients}

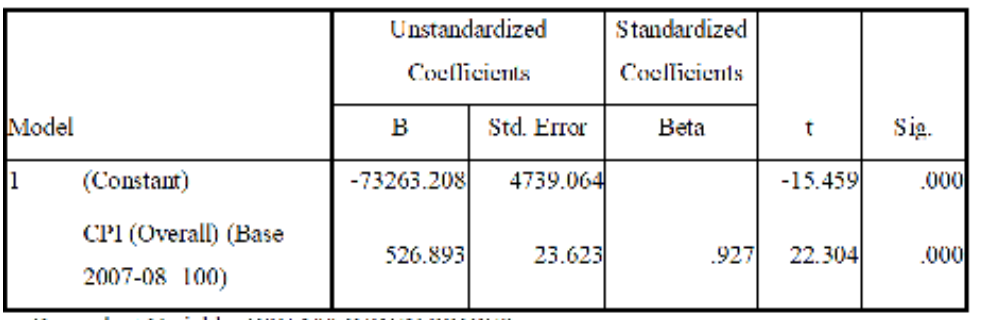

a. Dependent Variable: KSE' 100 INDEX P'RICES

Stock Prices (KSE 100 Index $)=-73263.208+526.893(\mathrm{CPI})$

This means that when inflation declines by 1 unit, stock prices will rise by 526,893 units. Here is a negative beta sign that shows the negative relationship between inflation and purchase price. Himself. The value ( $p$-value) is 0.000 , which is less than 0.05 so we reject a null hypothesis and accept another hypothesis.

\section{Graphical Representation}

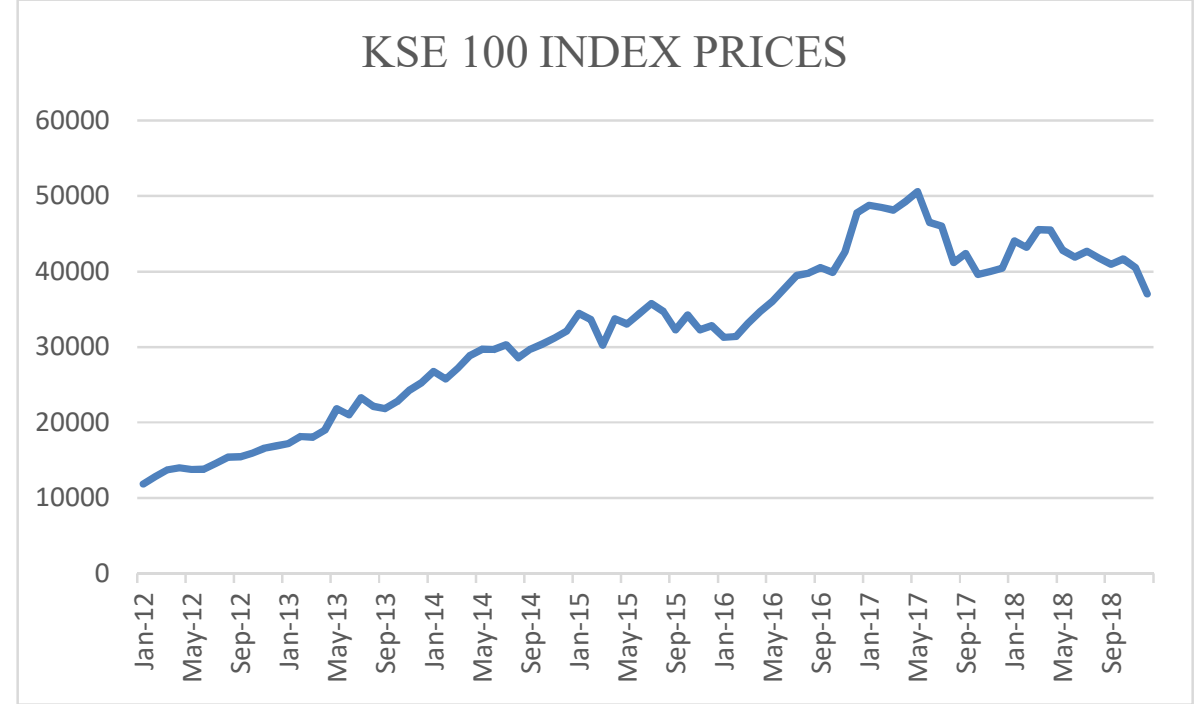

Figure no.1: shows a trend of KSE 100 index over a period of seven years. 


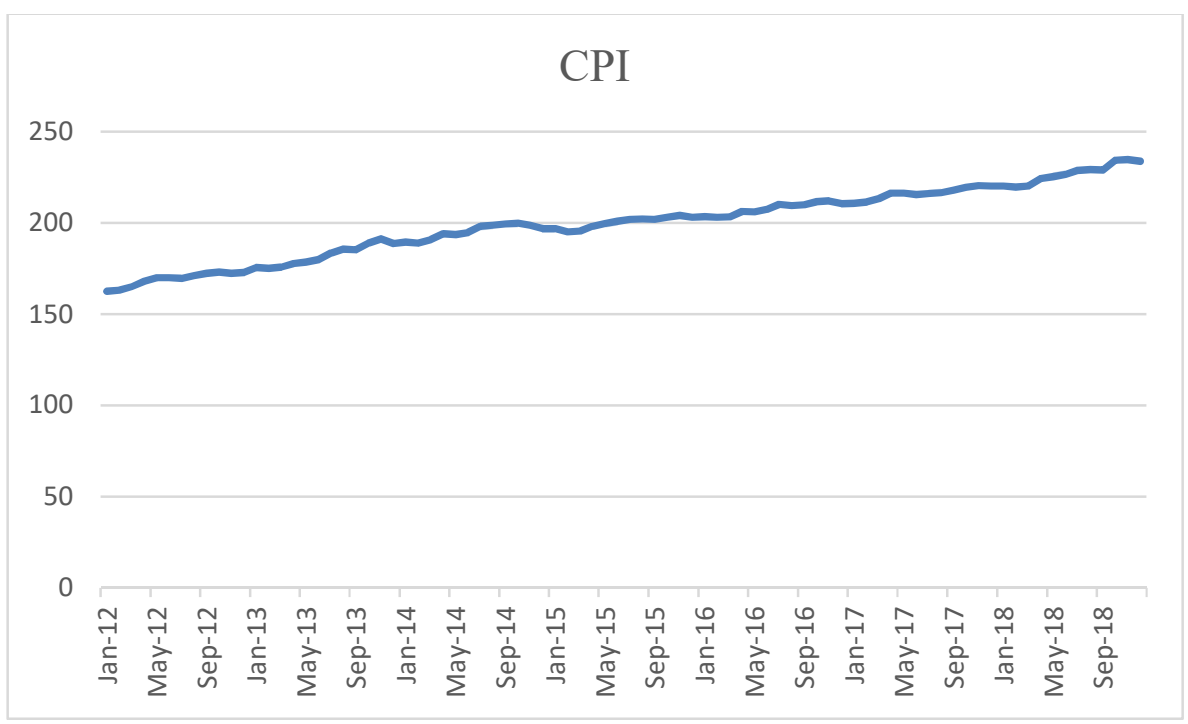

Figure no. 2 shows a trend of Inflation over a period of seven years.

\section{Conclusion}

By every passing day, the Pakistan economy is changing and effecting by different factors. In this study we focus on the relationship and effect of inflation on the stock prices in Pakistan, this study concludes by analyzing the data using regression model and the statistical results showing a negative relationship between inflation and stock prices. This study is very useful and informative for all the policy makers and investors.

Investors can track the performance of a stock market while making an investment. It is recommended that the government should make such kind of policies that increase the prices of stock while keeping the inflation rate in control. Further studies should explore the association between GDP, interest rate and exchange rate with stock prices.

\section{References}

1. Al-Abbadi HAD, Khaliq SA. The Relationship between Inflation and Stock Market Performance in Jordan. Research gate. European Journal of Business and Management. 2017:9(29):142-50.

2. Boudoukh J, Richardson M. Stock returns and inflation: A long-horizon perspective. The American economic review. 1993 Dec 1;83(5):1346-55.

3. Chidothi D, Sheefeni JP. The relationship between inflation and stock prices in Zambia. Asian Journal of Business and Management (ISSN: 2321-2803). 2013 Oct;1(04).

4. del Camino Torrecillas M, Jareño F. Inflation news impact on stock market: A review. Pensee. 2013 Nov;75(11):414-9.

5. e Wahid F. Does Stock Returns act as Hedge against Inflation in Pakistan? An empirical Analysis.

6. Farooq O, Ahmed N. Does inflation affect sensitivity of investment to stock prices? Evidence from emerging markets. Finance Research Letters. 2018 Jun 1;25:160-4.

7. Geetha C, Mohidin R, Chandran VV, Chong V. The relationship between inflation and stock market: Evidence from Malaysia, United States and China. International journal of economics and management sciences. 2011;1(2):1-6.

8. Ibrahim TM, Agbaje OM. The relationship between stock return and inflation in Nigeria. European Scientific Journal, ESJ. 2013 Feb 28;9(4).

9. Jaffe JF, Mandelker G. The" Fisher effect" for risky assets: An empirical investigation. The Journal of finance. 1976 May 1;31(2):447-58.

10. Jareño Cebrián F, Cuenca A, Escribano López AM. Macroeconomic Variables and Stock Markets: An International Study.

11. Khan J, Khan I. The impact of macroeconomic variables on stock prices: A case study Of Karachi Stock Exchange. Journal of Economics and Sustainable Development, 9 (13), 15. 2018;25. 
12. khan MN, Rizwan M, Islam F. Impact of Inflation on Stock Prices in Pakistan [Internet]. IRACST. International Journal of Commerce, Business and Management (IJCBM). 2016:5(2):355-65.

13. Khan MS. Macroeconomic variables \& its impact on KSE-100 Index. Universal Journal of Accounting and Finance. 2014 Apr;2(2):33-9.

14. Li L, Narayan PK, Zheng X. An analysis of inflation and stock returns for the UK. Journal of international financial markets, institutions and money. 2010 Dec 1;20(5):519-32.

15. Mahmood I, Nazir F, Junid M, Javed ZH. Stock prices and inflation: A case study of Pakistan. Journal of Asian Business Strategy. 2014;4(12):217-23.

16. Mishkin FS. The economics of money, banking, and financial markets. Pearson education; 2007.

17. Mousa SN, safi WA, Hasoneh AB, Abo-orabi MM. THE RELATIONSHIP BETWEEN INFLATION AND STOCK PRICES (A Case of JORDAN). IJRRAS. 2012 Jan:10(1):46-52

18. Naseem S, Mohsin M, Salamat S. Impact of Inflation on the Pakistan Stock Exchange. International Journal of Research. 2019;6(2):82-6.

19. Omran M, Pointon J. Does the inflation rate affect the performance of the stock market? The case of Egypt. Emerging Markets Review. 2001 Sep 1;2(3):263-79.

20. Otieno DA, Ngugi RW, Muriu PW. The impact of inflation rate on stock market returns: evidence from Kenya. Journal of Economics and Finance. 2019 Jan 1;43(1):73-90.

21. Qamri GM, Haq MA, Akram F. The Impact of Inflation on Stock Prices: Evidence from Pakistan.

22. Qayyum A, Anwar S. Impact of monetary policy on the volatility of stock market in Pakistan.

23. Rabia N, Khakan N. Impact of macro variables on Karachi stock exchange. Journal of Tourism and Hospitality. 2015;4(4):1-5.

24. Sohail N, Zakir H. Macroeconomic determinants of stock returns in Pakistan: the case of Karachi Stock Exchange. Journal of Advanced Studies in Finance. 2010 Dec 1;1(2):1817.

25. Yahyazadehfar M, Babaie A. Macroeconomic variables and stock price: new evidence from Iran. Middle-East Journal of Scientific Research. 2012;11(4):408-15.

\section{Data Sources}

1. Monthly Bulletin of Statistics, January 2018 [Internet]. Monthly Bulletin of Statistics, January 2018 | Pakistan Bureau of Statistics. [cited 2019May27]. Available from: http://www.pbs.gov.pk/content/monthly-bulletin-statistics-january-2018

2. psx.com.pk. [cited 2019May27]. Available from: https://www.psx.com.pk/

\section{Appendix}

\begin{tabular}{|r|r|r|}
\hline MONTHS & KSE 100 INDEX PRICES & CPI \\
\hline Jan-12 & 11874.89 & 162.58 \\
\hline Feb-12 & 12877.88 & 163.07 \\
\hline Mar-12 & 13761.76 & 164.98 \\
\hline Apr-12 & 13990.38 & 168 \\
\hline May-12 & 13786.62 & 169.93 \\
\hline
\end{tabular}




\begin{tabular}{|c|c|c|}
\hline Jun-12 & 13801.41 & 169.99 \\
\hline Jul-12 & 14577 & 169.57 \\
\hline Aug-12 & 15391.58 & 171.09 \\
\hline Sep-12 & 15444.82 & 172.44 \\
\hline Oct-12 & 15910.11 & 173.1 \\
\hline Nov-12 & 16573.86 & 172.42 \\
\hline Dec-12 & 16905.33 & 172.82 \\
\hline Jan-13 & 17242.74 & 175.7 \\
\hline Feb-13 & 18173.67 & 175.11 \\
\hline Mar-13 & 18043.31 & 175.82 \\
\hline Apr-13 & 18982.42 & 177.74 \\
\hline May-13 & 21823.05 & 178.65 \\
\hline Jun-13 & 21005.69 & 179.94 \\
\hline Jul-13 & 23312.78 & 183.58 \\
\hline Aug-13 & 22160.85 & 185.71 \\
\hline Sep-13 & 21832.68 & 185.18 \\
\hline Oct-13 & 22775.85 & 188.82 \\
\hline Nov-13 & 24302.19 & 191.21 \\
\hline Dec-13 & 25261.14 & 188.68 \\
\hline Jan-14 & 26784.34 & 189.6 \\
\hline Feb-14 & 25783.28 & 189 \\
\hline Mar-14 & 27159.91 & 190.82 \\
\hline Apr-14 & 28912.98 & 194.06 \\
\hline
\end{tabular}




\begin{tabular}{|c|c|c|}
\hline May-14 & 29737.69 & 193.55 \\
\hline Jun-14 & 29652.53 & 194.74 \\
\hline Jul-14 & 30314.07 & 198.05 \\
\hline Aug-14 & 28567.74 & 198.7 \\
\hline Sep-14 & 29726.39 & 199.4 \\
\hline Oct-14 & 30376.53 & 199.81 \\
\hline Nov-14 & 31197.98 & 198.79 \\
\hline Dec-14 & 32131.28 & 196.79 \\
\hline Jan-15 & 34443.87 & 196.95 \\
\hline Feb-15 & 33632.19 & 195.13 \\
\hline Mar-15 & 30233.87 & 195.57 \\
\hline Apr-15 & 33729.96 & 198.16 \\
\hline May-15 & 33056.79 & 199.66 \\
\hline Jun-15 & 34398.86 & 200.89 \\
\hline Jul-15 & 35741.52 & 201.91 \\
\hline Aug-15 & 34726.51 & 202.25 \\
\hline Sep-15 & 32287.41 & 202.04 \\
\hline Oct-15 & 34261.6 & 203.03 \\
\hline Nov-15 & 32255.2 & 204.22 \\
\hline Dec-15 & 32816.31 & 203.06 \\
\hline Jan-16 & 31298.6 & 203.5 \\
\hline Feb-16 & 31369.51 & 203 \\
\hline Mar-16 & 33139 & 203.3 \\
\hline
\end{tabular}




\begin{tabular}{|c|c|c|}
\hline Apr-16 & 34719.29 & 206.4 \\
\hline May-16 & 36061.56 & 206 \\
\hline Jun-16 & 37783.54 & 207.3 \\
\hline Jul-16 & 39505.28 & 210.1 \\
\hline Aug-16 & 39809.58 & 209.5 \\
\hline Sep-16 & 40541.81 & 209.9 \\
\hline Oct-16 & 39893.84 & 211.6 \\
\hline Nov-16 & 42622.37 & 212 \\
\hline Dec-16 & 47806.97 & 210.6 \\
\hline Jan-17 & 48757.67 & 210.9 \\
\hline Feb-17 & 48534.23 & 211.5 \\
\hline Mar-17 & 48155.93 & 213.3 \\
\hline Apr-17 & 49300.9 & 216.3 \\
\hline May-17 & 50591.57 & 216.3 \\
\hline Jun-17 & 46565.29 & 215.5 \\
\hline Jul-17 & 46010.45 & 216.2 \\
\hline Aug-17 & 41206.99 & 216.6 \\
\hline Sep-17 & 42409.27 & 218 \\
\hline Oct-17 & 39617.19 & 219.6 \\
\hline Nov-17 & 40010.36 & 220.4 \\
\hline Dec-17 & 40471.48 & 220.2 \\
\hline Jan-18 & 44049.05 & 220.3 \\
\hline Feb-18 & 43239.44 & 219.6 \\
\hline
\end{tabular}




\begin{tabular}{|r|r|r|}
\hline Mar-18 & 45560.3 & 220.3 \\
\hline Apr-18 & 45488.86 & 224.3 \\
\hline May-18 & 42846.64 & 225.4 \\
\hline Jun-18 & 41910.9 & 226.7 \\
\hline Jul-18 & 42712.43 & 228.8 \\
\hline Aug-18 & 41742.24 & 229.3 \\
\hline Sep-18 & 40998.59 & 229.1 \\
\hline Oct-18 & 41649.36 & 234.5 \\
\hline Nov-18 & 40496.03 & 234.8 \\
\hline Dec-18 & 37066.67 & 233.8 \\
\hline
\end{tabular}

